\title{
RESEARCH PAPER \\ EVALUATING THE LEVEL OF PHYSICAL TRANSFORMATION OF HOUSES IN GATED COMMUNITIES IN GHANA
}

\author{
J. A. Danquah ${ }^{1}$, S. O. Afram ${ }^{2}$ and P. A. Ofori ${ }^{1}$ \\ ${ }^{1}$ CSIR-Building and Road Research Institute, Kumasi, Ghana \\ ${ }^{2}$ Dept of Architecture, KNUST, Kumasi, Ghana \\ Corresponding author: joedanquah@gmail.com
}

\begin{abstract}
The upsurge of real estate housing within Accra has resulted in all manner of gated communities springing up across the city scape. These seek to provide housing services to the desperate urban dweller. The quality of their services has however been brought to question due to lack of a proper regulatory body to oversee their work. Recent studies indicate the emergence of physical transformations. This research sought to investigate the conditions and reasons underlying these housing transformations. A case study approach, with a mix of both qualitative and quantitative methods were adopted in determining the conditions of the houses. The relative important index was also used in ranking the various factors that led to these physical transformations. The study revealed that $41 \%$ of the houses have undergone transformations with external works, fenetrations, and mechanical and engineering services being most parts affected. Major reasons given for transformation were poor ventilation and lighting. The study recommends amongst others that the government should institute a special regulatory body backed by law with regular assessment from the occupants in order to check the performance of real estate developers.
\end{abstract}

Keywords: Gated community, real estates, physical transformation, housing

\section{INTRODUCTION}

Housing demand in Ghana has been rising over the years without any commensurate provision for the supply to meet this demand. This has widened the housing deficit from 1.5 million in 2,000 to about 2.1 million in 2014 . It is projected to reach 3.6 million in 2022 (Ghana Statistical Service-GSS 2010). Accra as the capital city of Ghana, like any other developing city, is most affected by this phenomenon. Buckley and Malhema (2009) in a report to the World Bank described the city as a Superstar Cityone where housing demand far outstripped supply. This has resulted in the springing up of many real estate houses, which have taken advantage of the situation to provide "substandard" housing for the desperate urban dwellers. According to the GREDA President 
there is no oversight body with legal backing to properly regulate their activities (Dopoah-Dei, 2015), with the exception of the Municipal and Metropolitan authorities, which also lack the trained professionals to regulate these large developments. A recent study on residential user satisfaction of real estates in Ghana (Danquah and Afram, 2014) revealed that many of these private real estate houses have undergone physical transformation. This phenomenon seems to be a typical manifestation of privatisation of public housing (Sefika, 2012). This transformation phenomenon refers to a change in the physical appearance of the house from its original appearance after occupation.

The objective of this research therefore is to investigate the housing conditions of these real estates and reasons that have prompted the occupants to undertake such transformations. The research was primarily conducted through a qualitative case study approach with semistructured questionnaires distributed to occupants of some selected real estate houses in Accra. The study was limited to real estates who allowed the research to be undertaken on condition of anonymity. The research is very relevant to the entire built environment professionals as it brings to the fore the real performance of these estate developments as well as serve as a feedback from occupants on their real needs.

\section{LITERATURE REVIEW}

\section{Post occupancy evaluation (POE)}

Post occupancy evaluation (POE) originates from "an interest in learning how a building performs once it is built, including if and how well it has met expectations and how satisfied building users are with the environment that has been created" (Vischer, 2002). The definition of POE has evolved since its inception about 40 years ago. Preiser et al. (1989) offered a definition of post-occupancy evaluation as "the process of evaluating buildings in a systematic and rigorous manner after they have been built and occupied for some time."
It may also mean any and all activities that originate out of an interest in learning how a building performs once it is built, including if and how well it has met expectations and how satisfied building users are with the environment that has been created (Preiser, 1989). The pioneers in the POE were the British, the French, and the North Americans, where the idea that a better living space could be designed by having better information from users drove environmental evaluation. Their focus was on the housing needs of the disadvantaged groups and efforts to improve environmental quality in government sub standardized housing (Vischer, 2002). User preferences became the legitimized aim of building research and a form of building evaluation after the initial concept of POE has been generally accepted.

Bordass and Leaman (2005), argue that the relationship between buildings and occupiers is constantly changing, with frequent clashes between operational requirements and physical facilities. Whilst designers seldom get feedback, they only notice a problem when asked to investigate a failure. The occupant's knowledge of his habitat is also not being used adequately to inform designers. Facilities' managers are hardly involved in briefing and there is no natural home for their experience. In their view occupant needs versus the built environment or products are construed as performance.

The famous Roman Architect Vitruvius (1960) pronounced three basic performance requirements of a building as firmness, commodity and delight. This historic construct was later transformed and synthesized into the "Habitability Framework" (Preiser, 1989) by devising three levels of priority as depicted in Fig. 1.

1. Health, safety, and security performance;

2. Functional, efficiency, and work flow performance; and

3. Psychological, social, cultural, and aesthetic performance levels. 


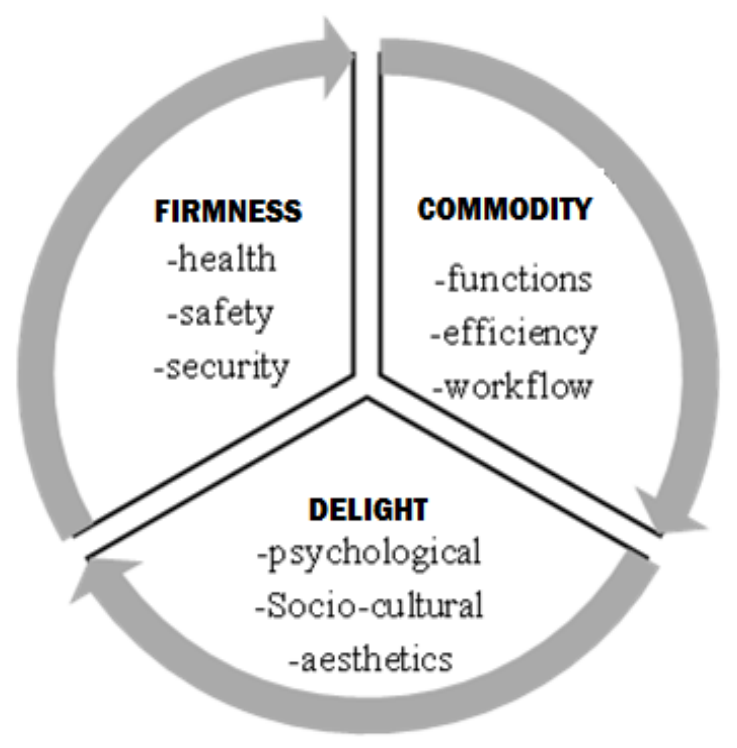

Fig. 1: Extract from habitability framework (Preiser 1988)

Preiser, (2001) further explained that the three levels that parallel the standards and guidance for designers to avail themselves to were:

A. Building codes and life safety standards

B. State of the art knowledge of products, building types and reference materials, and

C. Research based design guidelines

The principal focus on user experience remains central to most contemporary approaches to POE, and recent developments are characterized by two trends: the creation of standardized POE methodologies for specific building types (e.g. offices, healthcare and educational facilities) and the extension of the scope of POE activities to incorporate evaluation and feedback at repeated intervals during the building delivery lifecycle (Stevenson, 2009, as cited in Taylor et al, 2010). Over the years, this discipline has expanded and become more specialized, and various terms are used to describe it; facility performance evaluation, environmental design evaluation, environmental audits, building-in-use assessment, building evaluation, facility assessment, and building performance evaluation (Zimring et al., 2010).

In summary, the framework systematically relates buildings and settings to building occupants and their respective needs in relation to the product or the environment. It represents a conceptual, process-oriented approach that accommodates relational concepts to applications in any type of building or environment (Preiser, 1989).

\section{The need for post occupancy evaluation}

Enhancing, and with ever greater demands on limited resources, POE constitutes a potentially vital contribution in the effort to maintain quality assurance within the government, the downsizing of in-house facilities engineering as stated by the USA Federal Facility Council (Council, 2002). The reasons for POE are firstly, to develop knowledge about the long- 


\section{7}

Danquah et al.

term and even the short-term results of design and construction decisions, i.e. on costs, occupant satisfaction, and such building performance aspects as energy management (Taylor et al, 2010).

Secondly, to accumulate knowledge to inform and improve the practices of building-related professionals such as designers, builders, and facility managers and even to inform the clients and users who are the consumers of services and products of those same building-related professionals (Preiser and Vischer, 2006).

Thirdly, POE studies can provide feedback on occupant satisfaction, on building performance, and on operating costs and management practices. In sum, POE is a useful tool for improving buildings, increasing occupant comfort and managing costs (Preiser and Vischer, 2006).

\section{Gated communities in Ghana}

Gated communities as explained by Berkoz et al (2009), and ( Landman and Schönteich, 2002) are: "Residential areas for upper-class families who look for security, comfort, a better life quality and social homogeneity. They consist of neighbourhoods closed by walls, barriers, fences and gates. The concept includes residential areas with restricted access and defines a self-sufficient environment with swimming pools, private bars, children's play areas and a full accompaniment of care-taking staff and security forces (Landman, 2000)."

\section{Design considerations for a tropical country}

Ghana is a tropical country with temperatures varying in season and elevation. Annual rainfall ranges from about $1,100 \mathrm{~mm}$ (about 43ins) in the north to about $2,100 \mathrm{~mm}$ (about 83ins) in the southwest. The harmattan, a dry desert wind, blows from the northeast from December to March, lowering the humidity and creating hot days and cool nights in the north. In the south the effects of the harmattan are felt in January. In most areas the highest temperatures occur in March, the lowest in August (Ghana Meteorological Agency, 2014). In Accra the average daily temperature is $20^{\circ} \mathrm{C}$ and $36^{\circ} \mathrm{C}$ for minimum and maximum respectively. Humidity rages from $30 \%$ to $90 \%$.

Therefore designers must take into consideration certain elements that will help mitigate the harsh and uncomfortable effects of this climate. Thus there is a shift towards passive designs for this type of climate. Passive designs in the tropics make effective usage of the natural day lighting and cooling breezes, and use shading, orientation and appropriate materials to reduce heat gains and storage.

Designing to meet the comfort of occupants of buildings will generally require the consideration of the following:

- Well drained roof and wide eaves as well as ceiling vents;

- Wide verandas and covered porches;

- Protected openings;

- Orientation of the building to the northsouth;

- $\quad$ Aligning windows for effective cross ventilation and day lighting; and

- Use of courtyards.

The National Building Regulation, 1996 (LI 1630 ) is the regulatory document for all building developments in the country. Adequate provisions have been made in this document in order to realise the aforementioned, that is, orientation, ventilation and natural movement, natural lighting, spatial requirements, landscaping/surroundings. These have been summarized in the Table 1.

Careful consideration of these as seen in Table 1 will provide the needed thermal comfort for the occupants of such buildings. For example the positioning of the building should be done in such a way that most of the walls are shaded 
Physical transformation of houses in gated communities...

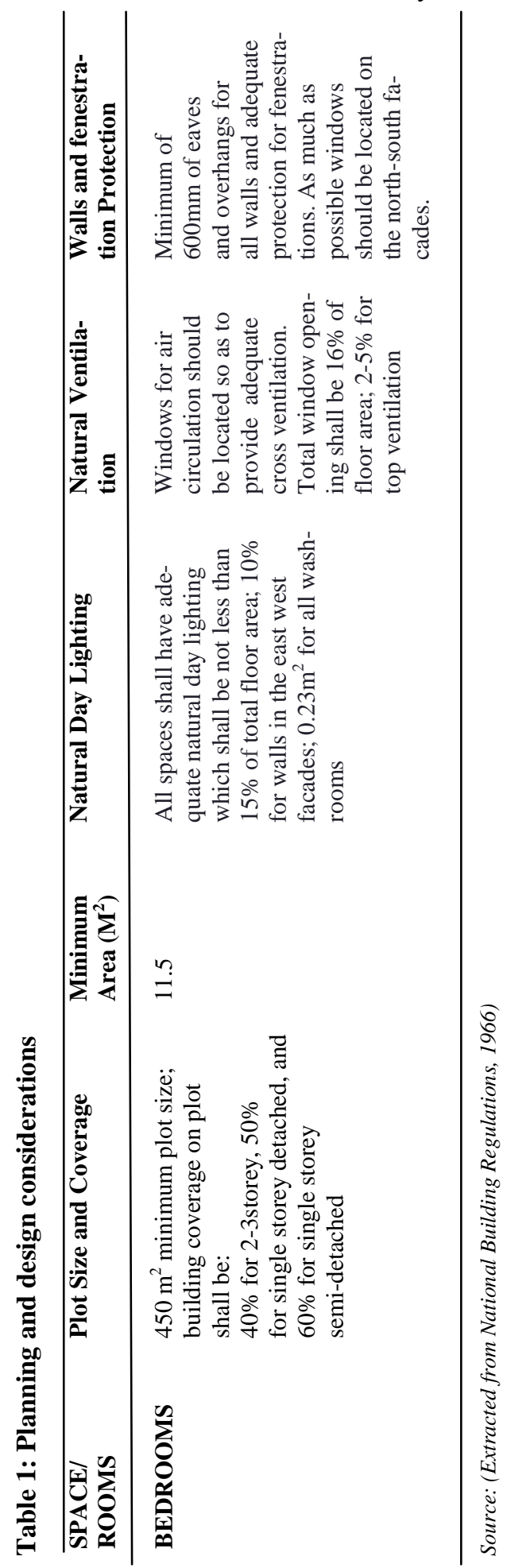

from direct sunlight and at the same time allowing for maximum air flow and light. Again landscaping elements such as trees, hedges, and lawns can help reduce temperatures by as much as $50^{\circ} \mathrm{C}$ compared to paving (Cairns Regional Council, 2011).

\section{Housing transformation in developing coun- tries}

Transformation has been seen as a typical manifestation of public housing privatisation as reviewed by a host of researchers (Sefika, 2012). However this is much less manifested in real estate (gated communities) which are governed by rules and regulations.

Key factors that account for these transformations assigned by authors such as Tipple and Ameen(1999), Kardash and Wilkinson(1991) and Sibley-Behloul (2002) include: secure tenancy and ownership, household size and composition, income and wealth, and expenditure on transformations. Secondly, in the housing environment, changes brought about by transformation have a particular effect on the livelihood of house members. For instance, Tipple and Ameen (1999) as cited in Awuvafoge (2013) noted that the effect of transformations on housing conditions includes, increase in house size, space occupied by the main household, increases in space occupied by all the residents, services available, physical conditions, plan forms, densities, value and cost, and use of house for economic activity (Tipple, 1996; Kardash and Wilkinson, 1991). The following section looks at the factors that cause transformations followed by the impact of transformations in housing environments (Sefika, 2012).

International literature suggests that the following aspects play a role in the propensity to transform: age of household head, gender, education, employment, and house tenancy and ownership, income and wealth, and household size and composition (Tipple and Willis, 1991; Sibley-Behloul, 2002). General impacts related to these transformations (as cited in Sefika 
(2012) are:

1. Increment of house sizes;

2. Increase in settlement densities;

3. Improvement in access to sanitation in the house;

4. Tendency by transformers to utilize better quality materials;

5. Transformations on the house plan or form and new architectural patterns Resulting in a new urban morphology;

6. Increases in value and cost of the original core structure; and

7. Higher economic activity within the household or neighborhood.

\section{RESEARCH METHODOLOGY}

A case study with both qualitative and quantitative approach was adopted for this study. This approach was used to gather factual data to study their relationships in accordance with existing theories and findings through openended semi -structured questionnaire and interviews. A proportional sampling method was then used to select the houses for the study at both locations. This was to ensure that a fair and accurate representation of the sampling. Thus $50 \%$ of the houses at both locations were targeted by use of house numbers polled together and balloted to select the ones to be surveyed.

In order to ensure maximum responses to the semi structured questionnaires, respondents were briefed regarding the purpose of the survey and reassured that the information provided will be kept confidential and will be used for research purposes only. Houses that indicated that changes had occurred were further studied through visual observations and limited physical measurements due to security concerns of occupants. This was then compared with what is required under L.I. 1630 building code to ascertain their compliance level.

A Likert scale ranging from "5" = very good, "4"= good, "3"= cannot tell, "2"= bad and "1"= worse, was used to measure conditions on various housing components. The overall condition for each variable was analysed based on a mean score of 3.00 as positive indication of satisfaction, and mean values below 3.00 indicating dissatisfaction. The data collected was analysed using Statistical Package for Social Sciences (SPSS version 21.0), for frequency distribution of the variables under study, including mean, standard deviation and percentage scores of satisfaction.

\section{FINDINGS AND DISCUSSION \\ The study area}

The sites are located in the suburbs of East Airport in Accra North District and Dome Kwabenya in the Ga East District in the Greater Accra region. The sites picked were estates belonging to companies which have been in the real estate business for the past twenty years, belong to GREDA, and the houses surveyed were over ten years old. These sites are Gated Communities with sold out or rented houses and run by a private Estate Management Organisation, a subsidiary of the Real Estate Company.

\section{Sample population and response rate}

The two locations had a total number of 137 and 567 houses for Dome Kwabenya and East Airport respectively. In order to maintain a $95 \%$ confidence level and a 0.3 error level, the study aimed at surveying 143 respondents to be deemed successful for effective analysis but in order to increase the respondents rate a total of 352 questionnaires were distributed to house owners and tenants, at Dome and East Airport in the greater Accra region with a successful response of 292 .

\section{Characteristics of respondents}

Majority of the residents, i.e. $46.5 \%$ were between $31-50$ years old and in all $86.1 \%$ of the 
residents were above age 30 years of age signifying that the respondents are matured people. They were male dominated $(75.5 \%)$, of various religious faiths with Christianity as the dominant religion $(74 \%)$. Residents were well educated with $77.6 \%$ of the people having tertiary education and only $3 \%$ having basic education. Employment rate was high $(85.8 \%)$, with most of them in the Private sector $(47.9 \%)$ and selfemployment $(37 \%)$. Income level was high as more than $50 \%$ of the respondents indicated that their monthly incomes were above $\mathrm{GHC}$ 1000 (\$ 350). Most respondents (79.9\%) were married with moderate family sizes, $63 \%$ indicated a family size of $3-5$ and $30.7 \%$ had $1-2$ family size.

Further analysis aimed at exploring respondents housing structure type, revealed that $68.8 \%$ of them live in detached house types with only $6.2 \%$ living in condominium/flats. About $49 \%$ of the people who live in their area are the owners of the houses whiles $10.9 \%$ of them are caretakers. All the houses surveyed were buildings put up by the estate companies. For length of stay, $47.9 \%$ of the people have lived in the area for 6-10 years. When asked the mode of payment of rent, $52.1 \%$ indicated that they pay through instalment packages.

Housing condition and rate of transforma-
tion
Analysis of the internal consistency of hous-
ing conditions, parts transformed and reasons
for transformation
The study used a scale of $1-5$ to ask respond- ents to indicate their satisfaction level with respect to housing and transformation factors, where 5 is highly satisfied and 1 is highly dissatisfied. The reliability tests of these variables are given in Table 2. The items of the housing and neighbourhood facilities have acceptable internal consistency, $\alpha>0.7$ for all tested attributes.

\section{Housing condition}

Further analysis was conducted to explore the relative importance of the housing conditions of the respondents. Variables of interest included all the aspect of the respondent's house and their immediate environment (Table 3). Of all the variables interrogated, respondents indicated that they are in good conditions. (Mean value $\geq 2.5$ for all variables). The ranking obtained indicated that construction quality (RII=0.887), floor (RII = 0.872) and safety and security $(\mathrm{RII}=0.857)$ were ranked highest (best) in terms of how the respondents viewed them. Natural ventilation, privacy, day lighting and plumbing works were ranked $11^{\text {th }}, 12^{\text {th }}, 13^{\text {th }}$, and $14^{\text {th }}$ respectively indicating their dissatisfactory state among respondents.

\section{Transformation}

Further analysis was performed with the aim of exploring the nature and trend of transformations that respondents had made to their houses and related features. Analysis revealed that $41 \%$ of the houses indicated that there has been some form of transformation in their houses. Many parts of the houses have received some form of transformation (Table 4), with main

Table 2 : Reliability test of housing and environmental variables

\begin{tabular}{lcc}
\hline Attribute & Number of Items & Cronbach Alpha \\
\hline Housing Conditions & 14 & 0.839 \\
Extent of Building transformation & 15 & 0.914 \\
Reasons for transformation & 8 & 0.870 \\
Total variables & 37 & \\
\hline
\end{tabular}

Source: Field survey 2014

Journal of Science and Technology (C) KNUST December 2015 


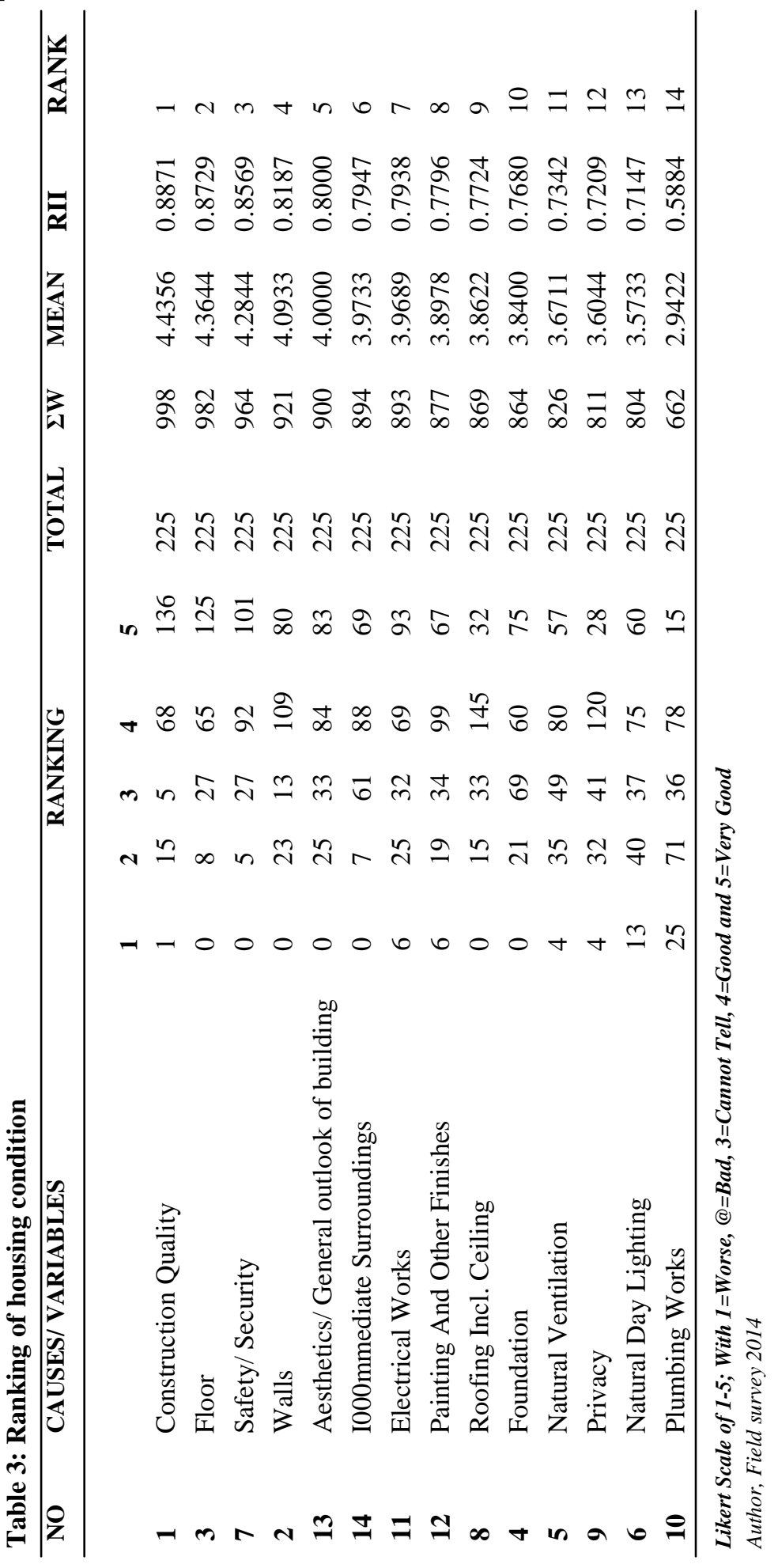

Journal of Science and Technology @ KNUST December 2015 
Physical transformation of houses in gated communities... 92

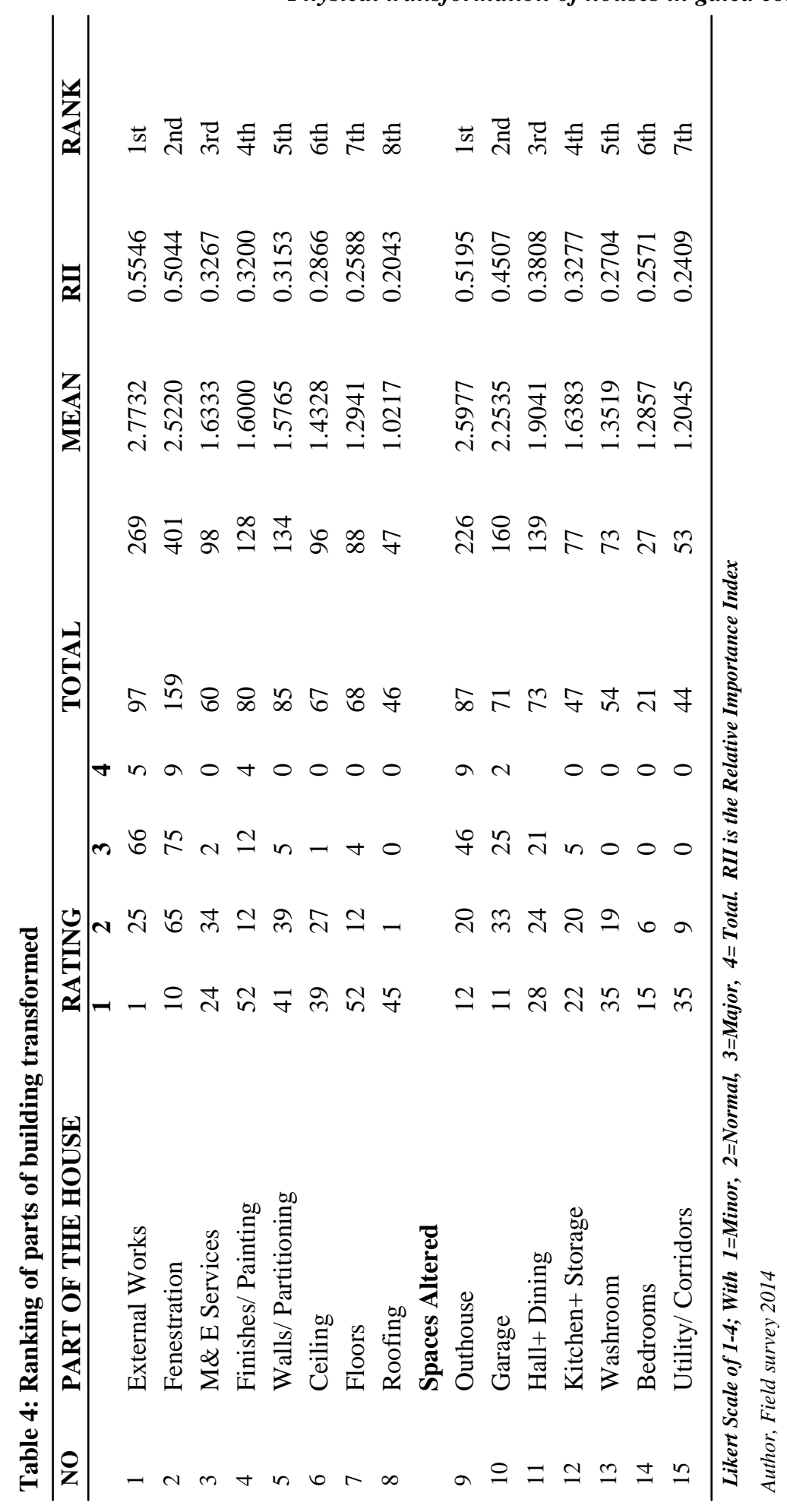

Journal of Science and Technology $\odot$ KNUST December 2015 


\section{Danquah et al.}

parts of building receiving major transformations being external works (Mean=2.77, RII= $0.55)$, fenestration (Mean=2.52, RII $=0.50)$, mechanical and electrical (Mean=1.63, RII= 0.33 ). On the other hand, floors (Mean=1.29, $\mathrm{RII}=0.26)$ and roofing $(\mathrm{Mean}=1.02, \mathrm{RII}=0.20)$ were less transformed. On the issue of room space alterations, outhouse (Mean=2.60, RII= $0.52)$ and garages $($ Mean=2.25, $\mathrm{RII}=0.45)$ were heavily transformed ranking $1^{\text {st }}$ and $2^{\text {nd }}$ respectively, whilst bedrooms and utility and corridors were the least transformed receiving a RII of 0.26 and 0.24 respectively.

\section{Neighbourhood facilities}

Exploration of the condition of their neighbourhood facility, which was to further find out the impact that transformation has had on these, revealed that $75 \%$ of respondents use their personal vehicle for transport, $50 \%$ of them have barb wire to secure their houses, $83.3 \%$ indicated that crime incidence was rare in the neighbourhood. The high income levels of these residents can be attributed to their mobility patterns, whilst the few ones without vehicles use the bus stop just at the entrance of the main gate. These neighbourhoods operate a $24 \mathrm{hr}$ security system with modern gadgets thus making crime very difficult. This sense of absolute safety can be attributed to the parking of vehicles within the compounds of the houses without using their purpose built spaces.

When respondents were asked to indicate factors that motivated the need for the transformation, poor ventilation (Mean=2.6, RII=0.52) and poor lighting $(\mathrm{Mean}=2.57, \mathrm{RII}=0.52)$ top the motivational factors. Reasons such as need for bigger space and additional rooms were least ranked with a RII of 0.436 and 0.427 respectively (Table 5).

A further analysis of the major reasons indicated that change in window sizes were the

Table 5: Ranking of reasons for transformation

\begin{tabular}{|c|c|c|c|c|c|c|c|c|c|}
\hline \multirow[t]{2}{*}{ NO } & \multirow[t]{2}{*}{ REASONS/ VARIABLES } & \multicolumn{3}{|c|}{ RATING } & \multirow[t]{2}{*}{ TOTAL } & \multirow[t]{2}{*}{$\Sigma \mathbf{W}$} & \multirow[t]{2}{*}{ MEAN } & \multirow[t]{2}{*}{ RII } & \multirow[t]{2}{*}{ RANK } \\
\hline & & 1 & 2 & 3 & & & & & \\
\hline $\mathbf{1}$ & Poor Ventilation & 6 & 74 & $\begin{array}{l}14 \\
5\end{array}$ & 225 & 589 & 2.618 & $\begin{array}{l}0.52 \\
4\end{array}$ & $1 \mathrm{st}$ \\
\hline 2 & Poor Lighting & 2 & 92 & $\begin{array}{l}13 \\
1\end{array}$ & 225 & 579 & 2.573 & $\begin{array}{l}0.51 \\
5\end{array}$ & 2nd \\
\hline 3 & Economic/Income Generation & $\begin{array}{l}1 \\
7\end{array}$ & $\begin{array}{l}10 \\
2\end{array}$ & $\begin{array}{l}10 \\
6\end{array}$ & 225 & 539 & 2.396 & $\begin{array}{l}0.47 \\
9\end{array}$ & $3 \mathrm{rd}$ \\
\hline 4 & Aesthetics /Beauty & $\begin{array}{l}3 \\
3\end{array}$ & 91 & $\begin{array}{l}10 \\
1\end{array}$ & 225 & 518 & 2.302 & $\begin{array}{l}0.46 \\
0\end{array}$ & 4 th \\
\hline 5 & $\begin{array}{l}\text { Poor Construction / } \\
\text { Workmanship }\end{array}$ & $\begin{array}{l}1 \\
1\end{array}$ & $\begin{array}{l}14 \\
5\end{array}$ & 69 & 225 & 508 & 2.258 & $\begin{array}{l}0.45 \\
2\end{array}$ & 5 th \\
\hline 6 & Need for Bigger Spaces & $\begin{array}{l}4 \\
5\end{array}$ & 85 & 95 & 225 & 500 & 2.222 & $\begin{array}{l}0.44 \\
4\end{array}$ & 6 th \\
\hline 7 & Additional Rooms & $\begin{array}{l}5 \\
0\end{array}$ & 85 & 90 & 225 & 490 & 2.178 & $\begin{array}{l}0.43 \\
6\end{array}$ & 7 th \\
\hline 8 & Others & 0 & $\begin{array}{l}19 \\
6\end{array}$ & 31 & 227 & 485 & 2.137 & $\begin{array}{l}0.42 \\
7\end{array}$ & 8th \\
\hline
\end{tabular}

Likert Scale of 1-3; With 1=Other, 2=Minor, 3=Major. RII is the Relative Importance Index

Source: Field survey 2013 
Physical transformation of houses in gated communities... 94

the most affected. The initial sizes were small sliding windows, which were not providing adequate lighting. Much critical was the severe reduction $(50 \%$ less) in ventilation due to the limitation in openings.

The study further revealed that though these transformations affected most parts of the building features, they were effectively controlled by the estate management company so as to ensure that these changes do not deviate from the identity of the gated community. However due to the option of the homeowner obtaining the services of outside artisans and professionals for these transformations, supervision of the work undertaken usually lacked the controls required to maintain the order within the neighbourhood.

These transformations can be classified into planned (option of expansion provided for) and unplanned (where the original design has been altered). For example, the study found majority of the planned transformation occurred with the construction of outhouses 1-bedroom expandable to 3-bedroom design option (see fig. 2). On the other hand the unplanned transformation had to do with the fenestration, creation and expansion of spaces. For instance, due to satisfaction in security and safety levels resulting in fewer crimes, many garages were being transformed into rooms for renting and household accommodation. Management could see the trend and put up measures to address these issues by paying more attention to the external works, doors and windows, floors, and plumbing works.

\section{Compliance to the national building regula-} tions

The study revealed that the building materials adopted generally conform to the provisions of the LI 1630. All the constructions were made of sandcrete block walls and concrete. Micro concrete tiles $(75 \%)$.

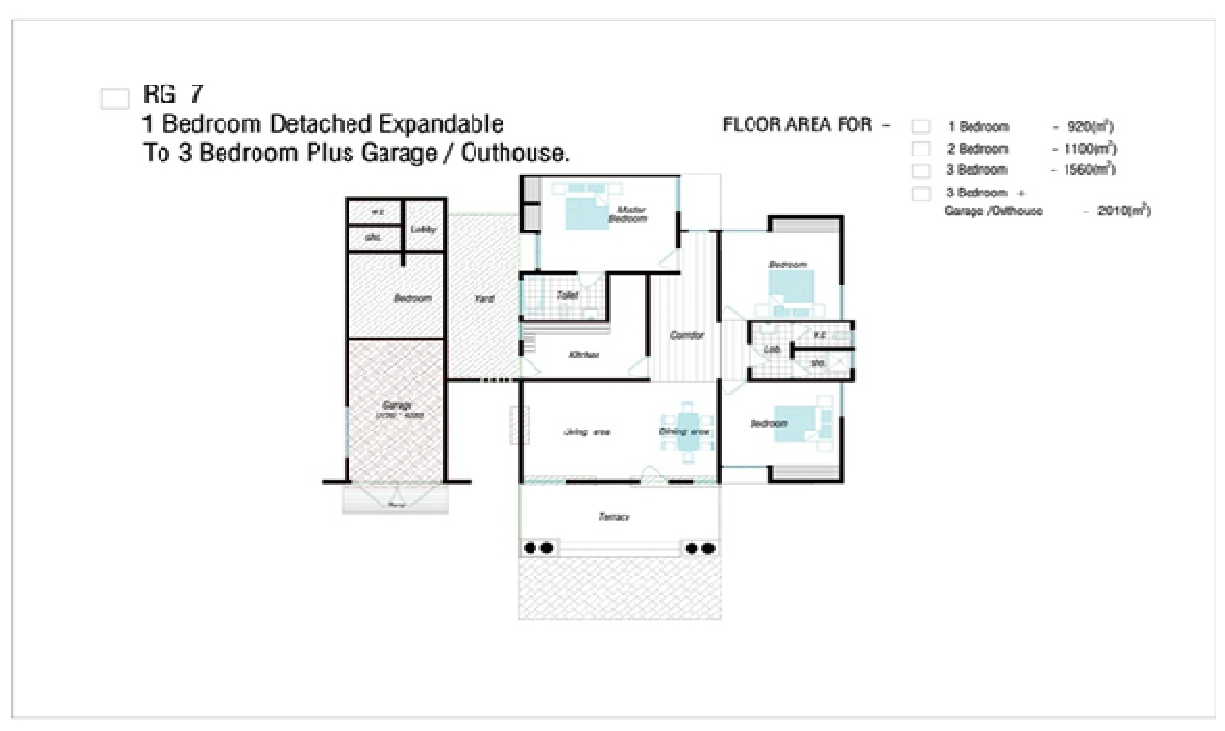

Fig. 2: Typical Floor plan showing main areas of transformation

Source: Author field study, 2014

Journal of Science and Technology @ KNUST December 2015 
formed the majority for the roofing, whilst the rest were long span aluminium sheets. Fenestrations were basically glass louvered and sliding windows. Build up areas of the plot sizes ranged from $25-35 \%$ well within the required $40 \%$. With respect to room sizes $85 \%$ of the spaces were adequate, with corridors, verandas and bathrooms falling just below the required area. The study revealed that two critical provisions- natural ventilation and lighting have been greatly compromised. For example most spaces had less than $10 \%$ of floor area as window sizes for ventilation as against the required minimum of $15 \%$. Corridors recorded less than $7 \%$. It was observed that the use of sliding windows also limited the flow of ventilation to these spaces as it limited by half the opening of the windows. On walls and opening protection, it is required that minimum of $600 \mathrm{~mm}$ eaves are projected but the average in these houses were $450 \mathrm{~mm}$. It thus noted that these shortcomings had influenced the kinds of transformations taking place within them. This confirms the reasons assigned by respondents for the transformations.

\section{CONCLUSION AND RECOMMENDA- TIONS}

The evidence indicates that many parts of the houses have received some form of transformation with the main part being external works, doors and windows, mechanical and electrical. This implies that residents are less satisfied with external works, doors and windows, floors and plumbing works. On the other hand, walls, roof and ceiling are less touched areas.

The analysis revealed that various factors motivated the need for the transformation. The need for adequate ventilation and lighting, and economic reasons topped the motivational factors. Issues such as poor construction and poor and inferior spaces also motivated a transformation but were of lower effect. It can also be seen that though there was a higher compliance to the building regulations one area that failed generally to meet this was in the area of ventilation. On the surface area of these windows one can say the areas provided were adequate, but the use of sliding windows effectively limited the ventilation area to just half of the window size. It is concluded that whilst management paid more attention to the main frame of the houses, less attention was given to fenestrations, services and external works. However the strict procedures adopted for any physical change to houses by the management has instilled some form of sanity and harmony in the neighbourhood. These rules are called Covenants, which has been agreed upon by both the home owners and the management and binds all to abide by them. For example, one cannot do an alteration to his or her building without seeking the consent of management and conforming to the laid out scheme and designs. The owner can then engage the management to effect the change at a fee or engage a private contractor but with supervision from the management. Penalties are paid for breaches.

It is important for management to address the taste of residents by performing actions such as increasing the number of rooms in the houses, improving construction quality and beautifying the landscape.

The study provides the following recommendations to enhance peoples' residential satisfaction and conditions in the Ghanaian real estates.

- There should be effective management of these estates with the urgent establishment of a proper legal regulatory body in collaboration with GREDA, Professional bodies such as Engineers, Planners and Architects and the Government. In this regard this regulatory body will be mandated to supervise the preparation and construction of these estates with their services being paid for by the real estate's companies and a percentage of the fee charged retained at the respective MMDA's to serve as additional income.

- Ghana Real Estate Industry could apply the knowledge that residents are satisfied with 
Physical transformation of houses in gated communities... 96

large room sizes, high quality houses to their future developmental plans. Taking this path will limit the rate and extent of transformations made to houses. This can be achieved by the conduct of regular occupants' satisfaction surveys.

- A critical look should be taken by the built environment professionals in developing countries to review the provision of traditional garages for gated community houses as there seems to be a shift away from traditional garages to open ports and open parking.

\section{REFERENCES}

Awuvafoge A. S. (2013). Affordable Housing in Urban Areas in Ghana: Issues and Recommendations. A thesis submitted to the Ball State University, Indiana for the award of Master of Urban and Regional Planning Degree.

Berkoz, L., Turk, Ş. Ş., and Kellekci, Ö. L. (2009). Environmental Quality and User Satisfaction in Mass Housing Areas: the case of Istanbul. European Planning Studies, 17(1): 161-174.

Bordass, B. and Leaman, A. (2005). Making feedback and post occupancy evaluation routine 1: A portfolio of feedback techniques. Building Research and Information, 33(4), 347-352.

Buckley, R. M. and Malhema, A. S. (2009). Is Accra a Superstar City? World Bank, Accessed from http://hdl.handle.net/00986/7521 in August, 2013.

Cairns Regional Council (2011). Sustainable Building Design; Guidelines for commercial buildings. 4-21, Cairns Regional Council, Australia.

Dopoa-Dei, K. (2015). Regulatory Body for Housing Long Overdue. In Daily Graphic of $9^{\text {th }}$ March , 2015. Accessed from http;//grap- http://graphic.com.gh/business/businessnews/39717-regulatory-body-for-housinglong-overdue-greda.html>

Federal Facilities Council (2002). Learning from Our Buildings: A State-of-the-Practice Summary of Post-Occupancy Evaluation (Federal Facilities Council Technical Report No. 145). Washington, National Academy Press

Francescato, G., Weidemann, S. and Anderson, J. R. (1989). Evaluating The Built Environment from the Users' Point of View: an attitudinal model of residential satisfaction. In Building evaluation. 181-198, Springer US.

Ghana Statistical Service - GSS (2010). Ghana Population and Housing Census 2010. Accessed from :http://www.statsghana.gov.gh/ pop_stats.html on June 2014.

Kardash, H. and Wilkinson, N. (1991). Development within development: user extensions of four walk-ups housing in Cairo-the case of Helwan. Open House International, 16(1): 9-17.

Landman, K. (2000). Gated communities and urban sustainability: Taking a closer look at the future. Proceedings: Strategies for a Sustainable Built Environment, Pretoria,1:1-8

Landman, K. and Schönteich M. (2002). "Urban Fortresses: Gated Communities as a Reaction to Crime." African Security Review, 11(4): 71-85.

Leaman, A., Stevenson, F. and Bordass, B. (2010). Building Evaluation: Practice and Principles. Building Research \& Information, 38(5): 564-577.

National Building Regulation, 1996 (L.I. 1630). Published by the Government Printer, Assembly Press, Accra Ghana.

Preiser, W. F. (1989). Towards a performance- 
based conceptual framework for systematic POEs. In Building evaluation, 1:1-7, Springer USA.

Preiser, W. F. and Vischer, J. C. (Eds.) (2006). Assessing Building Performance. Routledge, London. UK

Sam, M., Fauzi, M. and Saadatian, O. (2012). Residential Satisfaction and Construction. Journal of Scientific Research and Essays, 7 (15): 1556-1563.

Sefika M. S. (2012). The Privatisation Of Public Housing In South Africa: Incremental upgrading processes in Mangaung; Doctoral Thesis to the University of Free State. S.A

Sibley-Behloul, M. (2002). Informal transformations of formal housing estates in Algiers and Cairo. GBER, 2(3): 32-41.

Taylor, T., Littlewood, J., Geens, A., Counsell, J. and Pettifor, G. (2010). Developing postoccupancy evaluation techniques for assessing the environmental performance of apartment buildings in Wales: An Ecological Perspective, 1-15

Tipple, G. (1996). Housing Extensions as Sustainable Development, Habitat International, 20(3): 367-376.

Tipple, G. (2000). Extending Themselves: User -initiated Transformations of Governmentbuilt Housing in Developing Countries. Liverpool University Press. Liverpool.

Tipple, A. G., Owusu, S. E. and Pritchard, C. (2004). User-initiated extensions in govern- ment-built estates in Ghana and Zimbabwe: Unconventional but effective housing supply. Africa Today, 51(2): 79-105.

Tipple, A. G. and Ameen, S. (1999). User Initiated Extension Activity in Bangladesh: "Building Slums" or Area Improvement? Environment and Urbanisation, 11(1):165184.

Tipple A. G. and Willis, K. G. (Eds) (1991). Housing the Poor in the Developing World: Methods of Analysis, Case Studies and Policy. Routledge Publications. London and New York.

Varady, D. P. and Preiser, W. F. (1998). Scattered-Site Public Housing and Housing Satisfaction: Implications for the New Public Housing Program. Journal of the American Planning Association, 64(2): 189-207.

Vischer, J. (2002). Post-Occupancy Evaluation: a multifaceted tool for building improvement. Learning from out buildings: a state-of -the-practice summary of post-occupancy evaluation, 23-34

Vitrivous (1960), The Roman Architect Vitruvius. Dover publications, New York,17-34

Zimring, C., Rashid, M. and Kampschroer, K. (2010). Facility Performance Evaluation (FPE). In: Whole Building Design Guide: a program of the National Institute of Building Sciences. Accessed from: <http:// www.wbdg.org/resources/fpe.php> on July 26, 2010. 